\title{
CHANGES IN GROSS CALORIFIC VALUE OF THERMALLY TREATED SCOTS PINE (PINUS SYLVESTRIS L.) AND SESSILE OAK (QUERCUS PETRAEA L.) WOOD AND THEIR EXPLANATION USING FTIR SPECTROSCOPY
}

\author{
Emília Orémusová, Eva VÝ bohová \\ Technical University In Zvolen \\ Slova KIA \\ (Received May 2020)
}

\begin{abstract}
Scots pine (Pinus sylvestris L.) and Sessile oak (Quercus petraea L.) wood were thermally treated in an oven at the temperatures of $160^{\circ} \mathrm{C}$, and $200^{\circ} \mathrm{C}$ under atmospheric pressure in the presence of air for 3 and $9 \mathrm{hrs}$. The mass loss and gross calorific value were determined. Non-treated wood samples achieved a gross calorific value of $22193 \mathrm{~J} \cdot \mathrm{g}^{-1}$ for pine wood and $19277 \mathrm{~J} \cdot \mathrm{g}^{-1}$ for oak wood. Whereas the calorific value of pine wood with increasing severity of treatment decreased, in the case of oak it increased. The mass loss increased with increasing treatment severity by both wood species. Mentioned differences in pine and oak wood behaviour using ATR-FTIR spectroscopy were explained. In the case of pine wood with increasing temperature and time of exposure a decrease of resin acids was observed. This may be contributed to decrease in GCV. In the case of oak wood, mainly at temperature of $200^{\circ} \mathrm{C}$ the degradation of hemicelluloses was observed that results in relative increasing in the lignin content with followed increase in the GCV.
\end{abstract}

KEYWORDS: Gross calorific value, mass loss, pine, oak, thermal treatment, FTIR.

\section{INTRODUCTION}

Thermal treatment is a very effective way of improving the most important properties of wood. As a result of thermally induced chemical changes in the macromolecular constituents, the physical and biological properties of the wood are altered. Its ability to absorb water will be greatly reduced therefore it is particularly suitable for the production of wooden items that are used in humid environments. Moreover, its dimensional stability and the resistance to microbiological attack will be enhanced. Thermally treated wood does not need any coating or chemical preservatives. During treatment it becomes discolored to darker shades similar 
to tropical woods. Thanks to its improved properties it is increasingly used in a wide variety of areas (Hill 2006, Výbohová et al. 2018, Kúdela and Andor 2018, Esteves and Pereira 2009, Candelier 2016, Cademartori 2015, Dzurenda 2018, Dubey et al. 2012, Martinka et al. 2013). Various thermal treatment processes have been used on the present, which differences in the process conditions (temperature, duration, open or closed system, oxygen or nitrogen atmosphere, wet or dry process, use of oils, etc.) (Militz 2002, Bazyar 2012).

The heat treatment causes chemical changes in the wood. The changes due to heating depend on the duration and temperature of the treatment. Hemicelluloses are the most thermally labile of the wood polymeric components. At the beginning of treatment their depolymerization occurs whereby oligosaccharides and monosaccharides are formed. During their degradation methanol, acetic acid and various volatile heterocyclic compounds are produced. Because the presence of acetyl groups is a significant factor in the thermal degradation of hemicelluloses, hardwoods are less thermally stable than softwoods. Cellulose degradation occurs at a higher temperature than degradation of hemicelluloses, and begins in its amorphous regions. First, its degree of polymerization decreases, and subsequently carbonyl and carboxylic groups due to oxidation of the cellulosic $-\mathrm{OH}$ groups are produced. The degradation of polysaccharides results in an increase in the lignin content (Výbohová et al. 2018, Čabalová et al. 2018). It is generally accepted that lignin is the most thermally stable component of the cell wall. Nevertheless, some degradation of lignin can occurs at relatively low temperatures. The cleavage of $\beta-\mathrm{O}-4$ linkages and a decrease in methoxyl content leads to auto-condensation of lignin to a more condensed structure (Hill 2006, Esteves and Pereira 2009, Wikberg and Maunu 2004, Chen et al. 2012, Brebu and Vasile 2010). As regards extractives, the most volatile compounds leave the wood, while others are degraded. Nevertheless, some authors (Výbohová et al. 2018, Esteves et al. 2011, Wang et al. 2015, Severo 2016) found, that the content of extractives due to heating increased. That can be caused by the release of degradation products of lignin and saccharides in the extraction mixture, or by their condensation reactions with the extractives originally present in untreated wood.

Gross calorific value (GCV) is the absolute value of the specific energy combustion, in joules for unit mass of a solid fuel burned in oxygen in a calorimetric bomb under specified conditions. It can be defined as the total heat liberated by the complete combustion of the fuel. GCV assumes that the water of combustion is entirely condensed. Value of GCV depends on the chemical composition of materials (Dietenberger and Hasburgh 2016). GCV is an important characteristic not only from energetic but also fire protection and safety (Majlingová et al. 2019). Based on this value, the net calorific value is calculated, which serves as a parameter to calculate the fire loading when planning the fire protection of buildings.

The content of wood components and their elemental composition play an important role for its calorific value. Lignin is richer in carbon and hydrogen than polysaccharides. Because these elements produce heat by burning, the calorific value of lignin is higher than of carbohydrates that are richer in oxygen. Moreover, in hardwood lignins is due to higher amount of methoxyl groups higher oxygen content than that in softwood lignins, therefore their calorific values are lower (Hill 2006, Fengel and Wegener 1984, Hon and Shiraishi 2001, Santos et al. 2012). Although the extractives are a minor component of wood, they raise its calorific values. Out of all wood constituents, for extractives have been determined the highest GCV values (Dietenberger and Hasburgh 2016). Inorganic elements present in wood play also certain role. These elements will remain after burning as ash, whose content in wood ranges between 0.08 to $2.30 \%$. High content of inorganic elements in the fuel generally reduces its calorific value (Telmo and Lousada 2011, Dzurenda and Pňakovič 2016, Dzurenda et al. 2013). 
Several authors (Kúdela and Andor 2018, Čabalová et al. 2018, Wang et al. 2015, Andor and Lagaňa 2018, Bubeníková et al. 2018, Esteves et al. 2013, Barcík et al. 2015, Percin et al. 2016) studied the effect of thermal treatment on color, biological resistance, chemical and mechanical properties of wood. However, it can be assumed that changes in the ratio of main wood components caused by heating affected also the calorific value of thermally treated wood. Nevertheless, these features of thermally treated wood have seldom been studied.

In our research effect of thermal treatment under various process conditions (temperature and time) on the gross calorific value of treated wood was studied. Softwood and hardwood, Scots pine (Pinus sylvestris L.) and Sessile oak (Quercus petraea L.), were examined. Both wood species are an important raw material in building and wood processing industry (Klement et al. 2010). GCV using oxygen bomb calorimeter was determined. Chemical changes in wood due to thermal treatment using Fourier transform infrared (FTIR) spectroscopy were studied.

\section{MATERIAL AND METHODS}

\section{Materials}

In the experiments the samples of softwood (Pinus sylvestris L.) and hardwood (Quercus petraea L.) were used. Both trees were logged from altitude of $300 \mathrm{~m}$ above sea level, in Kremenny Jarok locality in the Slovak Republic. The timber logging activities were performed in summer period. The average stand age was 110 years. The stem breast height diameter of the Scots pine was of $36 \mathrm{~cm}$, timber moisture content of 30\%. The stem breast height diameter of the Sessile oak was of $45 \mathrm{~cm}$ and timber moisture content of 30\%, too.For Scots pine $654 \mathrm{~kg} \cdot \mathrm{m}^{-3}$ and for Sessile oak wood $695 \mathrm{~kg} \cdot \mathrm{m}^{-3}$ density at $0 \%$ moisture content was determined.

The samples were cut from the core part of the stem in longitudinal sections to dimensions of $10 \times 1 \times 2 \mathrm{~cm}$ and oven dried at temperature of $103 \pm 2^{\circ} \mathrm{C}$ until the weight of the samples was not stabilized and they reached $0 \%$ moisture content. Further, the samples were modified by the thermal treatment in the oven (Memmert UFP 500) at atmospheric pressure in the presence of air at temperatures of $160^{\circ} \mathrm{C}$ and $200^{\circ} \mathrm{C}$ for 3 hours and 9 hours. The treated samples were placed in a desiccator to eliminate the effect of moisture. Introduction of the test samples is shown in Tab. 1 and in Fig. 1.

Tab. 1: Data on the test samples.

\begin{tabular}{cccc}
\hline Tree species & Latin name & Identifications of the sample & Thermal treatment \\
\hline \multirow{4}{*}{ Scots pine } & P & no thermal treatment \\
& & $\mathrm{P} 160 / 3$ & $160^{\circ} \mathrm{C}, 3 \mathrm{hrs}$. \\
& & $\mathrm{P} 160 / 9$ & $160^{\circ} \mathrm{C}, 9 \mathrm{hrs}$. \\
& $\mathrm{P} 200 / 3$ & $200^{\circ} \mathrm{C}, 3 \mathrm{hrs}$. \\
& $\mathrm{P} 200 / 9$ & $200^{\circ} \mathrm{C}, 9 \mathrm{hrs}$. \\
\hline \multirow{3}{*}{ Sessile oak } & $\mathrm{O}$ & no thermal treatment \\
& & $\mathrm{O} 160 / 3$ & $160^{\circ} \mathrm{C}, 3 \mathrm{hrs}$. \\
& & $\mathrm{O} 160 / 9$ & $160^{\circ} \mathrm{C}, 9 \mathrm{hrs}$. \\
& & $\mathrm{O} 200 / 3$ & $200^{\circ} \mathrm{C}, 3 \mathrm{hrs}$. \\
& & $\mathrm{O} 200 / 9$ & $200^{\circ} \mathrm{C}, 9 \mathrm{hrs}$. \\
\hline
\end{tabular}




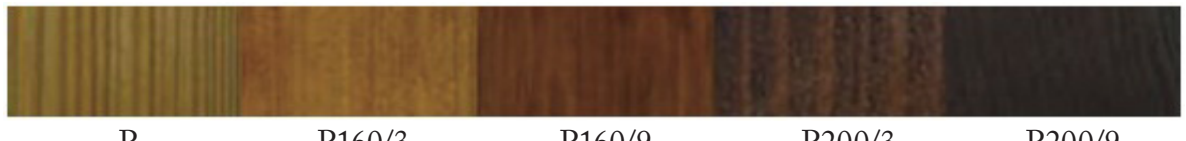
$\mathrm{P}$
$\mathrm{P} 160 / 3$
P160/9
P200/3
P200/9

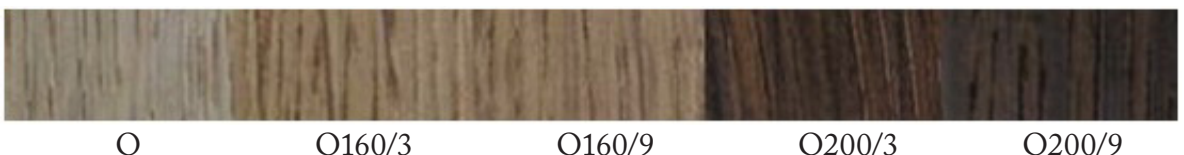

Fig. 1: Samples of Scots pine (Pinus sylvestris L.) and Sessile oak (Quercus petraea L.) wood before and after thermal treatment.

In the research, we first investigated the difference in weight of pine and oak samples after thermal treatment at temperatures of 160 and $200^{\circ} \mathrm{C}$, taking into consideration the duration of thermal treatment ( 3 and $9 \mathrm{hrs}$ ). The mass loss was determined gravimetrically on the basis of the sample weights before and after the thermal treatment.

The gross calorific value was determined using a fully automatic calorimeter IKA C 5000 control (IKA-WERKE GMBH) under adiabatic conditions, in a setting without titration. Calculations correspond to the applicable standards ISO 1928 for gross calorific value determination.

The principle of the determination of the GCV consists of the complete combustion of the sample in oxygen at a pressure of $3 \mathrm{MPa}$ in a calorimetric pressure vessel, in measuring the temperature rise in the calorimetric vessel and the determination of heat corrections. The weight of the samples was about $0.80 \mathrm{~g}$. The samples were tested at $0 \%$ moisture content. From each set of samples, the GCV was determined by min 3 measurements. The GCV values for pre-defined samples moisture content of $8 \%$ were calculated according to the ISO 1928 standard.

Fourier transform-infrared (FTIR) spectra of the wood samples were recorded using the Nicolet iS10 FTIR spectrometer equipped with Smart iTR attenuated total reflectance (ATR) sampling accessory with diamond crystal (Thermo Fisher Scientific, Madison, WI, USA). Wood samples were disintegrated into sawdust and the average samples were analyzed. Spectra were measured in the wavenumber range from 4000 to $650 \mathrm{~cm}^{-1}$. A resolution of $4 \mathrm{~cm}^{-1}$ and 32 scans per sample were used. Measurements were performed on four replicates per sample and average spectra were created and evaluated. The OMNIC 8.0 software (Thermo Fisher Scientific, Madison, WI, USA) was used to evaluate the spectra.

\section{RESULTS AND DISCUSSION}

\section{Mass loss}

When wood is modified by thermal treatment, there is a significant change in the color of the wood, in the chemical composition of wood and also mass loss. The change in mass loss is one of the most important features in the thermal treatment of wood, and is commonly referred to as an indicator of quality (Esteves and Pereira 2009). The results of mass loss due to sample thermal treatment are shown in Fig. 2. From the Fig. 2, we can see substantial changes in mass loss of samples. In both species, the mass loss increased with increasing temperature and thermal treatment duration, although 
at temperature of $160^{\circ} \mathrm{C}$ the mass loss was higher for Scots pine wood, while at temperature of $200^{\circ} \mathrm{C}$ the mass loss was higher for Sessile oak wood regardless of the treatment duration. Different behaviour of Scots pine and Sessile oak wood is caused by different chemical composition of investigated wood species. Scots pine wood is characterized by a high proportion of volatile extractives, which are largely released from wood at a lower thermal treatment temperature (Ekeberg 2006, Traoré 2018).

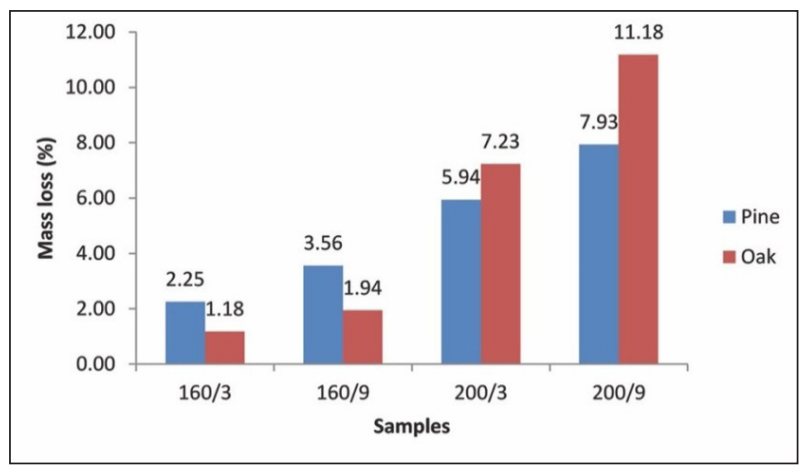

Fig. 2: Mass loss of samples after thermal treatment.

Another significant factor is the different content and composition of hemicelluloses in Scots pine and Sessile oak wood. In comparison to Scots pine, Sessile oak wood contains higher proportion of hemicelluloses, higher proportion of pentosanes and more acetyl groups in hemicellulose polysaccharides. At a temperature near $200^{\circ} \mathrm{C}$, glycosidic linkages are ruptured as well as some C-C bonds of pyranose rings (Fengel and Wegener 1984). Also Výbohová et al. (2018) found that the degradation of hardwood hemicelluloses is more pronounced at $200^{\circ} \mathrm{C}$ than at $160^{\circ} \mathrm{C}$. That is why we observed higher mass loss at temperature $200^{\circ} \mathrm{C}$ in the case of Sessile oak wood compared to Scots pine wood.

The mass loss during the thermal treatment depends on the wood species, biotope, the temperature and the duration of the thermal treatment (Luptáková and Kačík 2018). However, it is sometimes difficult to compare data published by different authors, as individual experiments often differ in thermal treatment conditions. In the literature (Gonzalez-Pena and Curling 2009) there are published changes in Scots pine wood during thermal modification at temperatures ranging from $190^{\circ} \mathrm{C}$ to $245^{\circ} \mathrm{C}$ using different exposure duration, i.e. 0.33 hour, 1 hour, 4 hours, 8 hours and 16 hours. In the case of Scots pine wood, the mass loss was of $0.6 \%$ (exposure duration of 0.33 hour) and $4.5 \%$ (exposure duration of 16 hours) at temperature of $190^{\circ} \mathrm{C}$. At temperature of $245^{\circ} \mathrm{C}$, it ranged between $5.6 \%$ (exposure duration of 0.33 hour) and $21.5 \%$ (exposure of 16 hours). The authors conclude that the mass loss of wood is more affected by the temperature of exposure than the duration of exposure and wood species. Mazela et al. (2003) treated Scots pine wood at temperatures of $160^{\circ} \mathrm{C}, 190^{\circ} \mathrm{C}$, and $220^{\circ} \mathrm{C}$ during 6 hours and 24 hours in both air and water vapor. They found that in both environments the mass loss was similar when exposed to thermal treatment for 6 hours. But when exposed to thermal treatment for 24 hours, the mass loss was higher in air, especially at treatment temperatures of $190^{\circ} \mathrm{C}$ and $220^{\circ} \mathrm{C}$. 


\section{Gross calorific value}

The GCV values of the test samples of thermally treated Scots pine wood and Sessile oak wood compared to the non-treated samples are shown in Fig. 3. The results of the determination of the GCV show different values between the non-treated samples of both wood species as well as the effect of duration and temperature of the thermal treatment. Higher GCV value was obtained for non-treated sample of Scots pine wood compared to Sessile oak wood. The difference between these values was of $2916 \mathrm{~J} \cdot \mathrm{g}^{-1}$ and it was caused by a different chemical composition of investigated wood species. It was found that energy content of different wood components varied depending on its elemental composition (Dietenberger and Hasburgh 2016, Geffertová 2009, Tillman 1978, White 1986). Lignin that is rich in carbon and hydrogen has a gross calorific value about $23.2-27.4 \mathrm{MJ} \cdot \mathrm{kg}^{-1}$. For holocellulose that has higher oxygen content the GCV in the range $17.5-18.8 \mathrm{MJ} \cdot \mathrm{kg}^{-1}$ was found. The highest GCV values (about $32-37 \mathrm{MJ} \cdot \mathrm{kg}^{-1}$ ) were found in extractives. In general, hardwoods contain more hemicelluloses than softwoods but less lignin (Baeza and Freer 2001). Therefore the GCV of Sessile oak wood might be lower than Scots pine wood. In addition, Scots pine wood is characterized by a high resin content, which also increases its GCV. Other authors reported GCV values for Sessile oak of $19685 \mathrm{~J} \cdot \mathrm{g}^{-1}$ and Scots

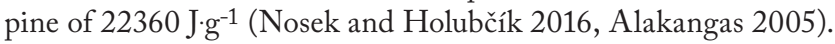

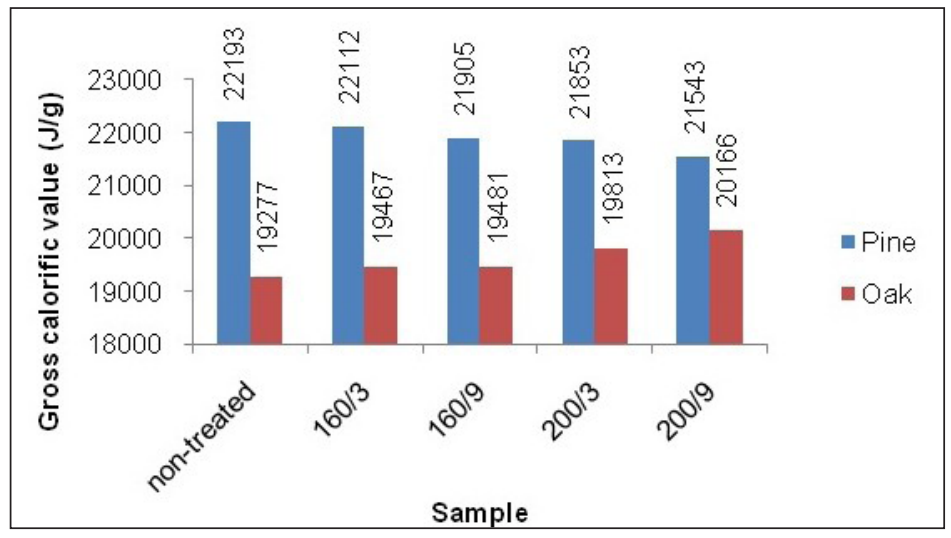

Fig. 3: Gross calorific value of Scots pine and Sessile oak wood.

Changes in GCV of Scots pine and Sessile oak wood caused by thermal treatment have an opposite trend. During the thermal treatment of the Scots pine wood a downward trend in GCV values with increasing temperature and treatment duration was observed. For sample P160/3, the GCV decreased by $0.35 \%$, for sample P160/9 by $1.30 \%$, for sample P200/3 by $1.53 \%$, and for sample P200/9 by $2.93 \%$, compared to non-treated Scots pine sample. On other hand, the GCV values increase with increasing temperature and thermal treatment duration in the case of Sessile oak wood. The GCV increase by $0.95 \%$ for sample O160/3, by $1.06 \%$ for sample $\mathrm{O} 160 / 9$, by $2.78 \%$ for sample O200/3 and by $4.61 \%$ for sample O200/9, compared to non-treated Sessile oak wood.

The GCV values shown in Fig. 3 were determined at $0 \%$ moisture content. We chose these conditions to make the results comparable to each other and not to be affected by the moisture content factor. This is the worst scenario in terms of fire protection. In general, the GCV values decrease with increasing moisture content. In practice, each wood product has a certain moisture 
content, which also applies to thermo-wood, but in the case of thermally treated wood, there can be found the decrease in its equilibrium moisture content and consequently also decrease in its swelling and drying. Compared to non-treated wood, thermally treated wood absorbs significantly less moisture in the form of water vapor. The hygroscopic equilibrium moisture of thermally treated wood is about $30-50 \%$ lower than any of other wood, including impregnated wood. At a temperature of about $20^{\circ} \mathrm{C}$, when the relative humidity of the air is about $60-70 \%$, the equilibrium moisture content of the thermally treated wood is about $6-7 \%$. If the air relative humidity rises to $80 \%$, the equilibrium wood moisture content is about $8 \%$. Thus, the moisture content of thermally treated wood is about 6-8\% (Reinprecht and Vidholdová 2011). Tab. 2 shows the values of gross calorific value calculated to $8 \%$ moisture content.

Tab. 2 Resulting GCV at $8 \%$ moisture content.

\begin{tabular}{lc}
\hline Sample & Gross calorific value $\left(\mathbf{J} \cdot \mathbf{g}^{-1}\right)$ \\
\hline $\mathrm{P}$ & $20418 \pm 80.21$ \\
$\mathrm{P} 160 / 3$ & $20344 \pm 93.83$ \\
$\mathrm{P} 160 / 9$ & $20153 \pm 46.20$ \\
$\mathrm{P} 200 / 3$ & $20105 \pm 85.54$ \\
$\mathrm{P} 200 / 9$ & $19820 \pm 73.65$ \\
\hline $\mathrm{O}$ & $17735 \pm 42.57$ \\
$\mathrm{O} 160 / 3$ & $17910 \pm 52.72$ \\
$\mathrm{O} 160 / 9$ & $17928 \pm 18.66$ \\
$\mathrm{O} 200 / 3$ & $18228 \pm 91.10$ \\
$\mathrm{O} 200 / 9$ & $18553 \pm 28.38$ \\
\hline
\end{tabular}

It is known that chemical composition of wood varied due to its thermal treatment. In our experiments chemical changes using ATR-FTIR spectroscopy were studied (see Fig. 4 and Fig. 5).

In the Scots pine wood spectra, a decrease in the intensity of the typical absorption band for resin acids at $1693 \mathrm{~cm}^{-1}$ can be observed with increasing temperature and treatment duration. Also, a decrease in peak intensity in the range of $3000-2800 \mathrm{~cm}^{-1}$, which is attributed to the stretch vibrations of $-\mathrm{CH}$ in the $-\mathrm{CH}_{2}$ and $-\mathrm{CH}_{3}$ groups, may also be caused by the release of resin acids from wood. Many authors (Ekeberg 2006, Traoré 2018) found that resin acids are notable components in pine wood extractives. Furthermore, at the temperature of $200^{\circ} \mathrm{C}$ and treatment time $9 \mathrm{~h}$ the decrease in intensity of characteristic peaks for aromatic skeletal vibrations at wavenumber $1510 \mathrm{~cm}^{-1}$ can be observed. This might be caused by degradation of lignin and aromatic extractives. Although lignin is considered to be the most thermally stable component of wood, some thermal degradation of lignin can occur at relatively low temperatures (Hill 2006, Brebu and Vasile 2010). From aromatic extractives pine wood contains mainly phenolic compounds, which cause darkening of wood in the light and have been implicated in the decay resistance of pine wood and also stilbenes, especially pinosylvin (Fengel and Wegener 1984, Ekeberg et al. 2006). The decomposition of extractives due to thermal treatment contributes to the mass loss. Because extractives have a highest GCV values from all wood components, their decomposition and release from wood decreases the calorific value of thermally treated wood 


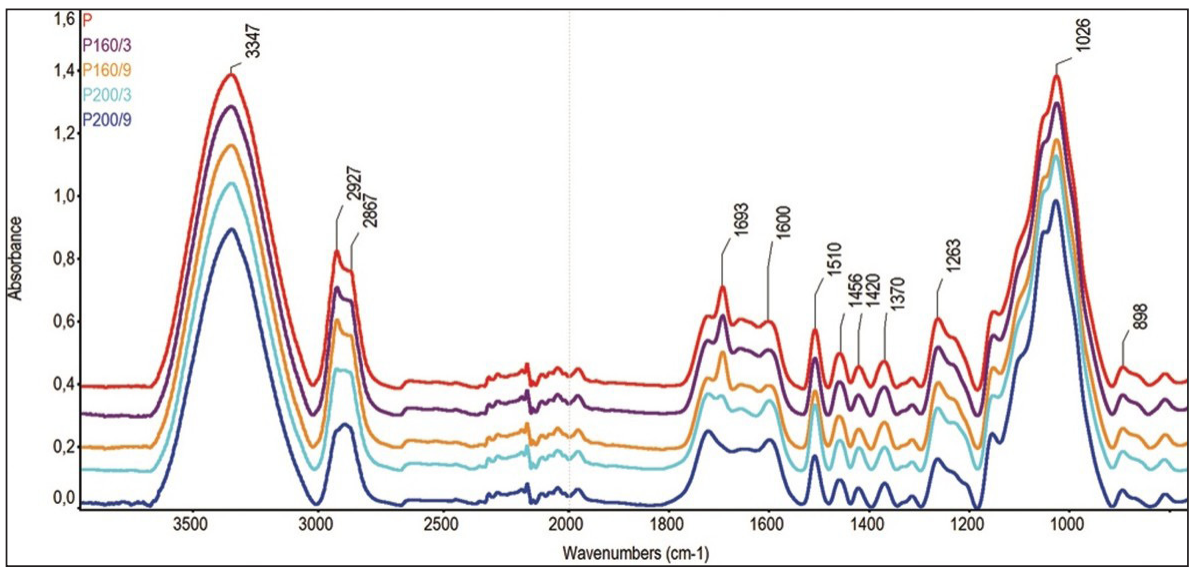

Fig. 4: FTIR spectra of non-treated and thermally treated Scots pine (Pinus sylvestris L.) wood.

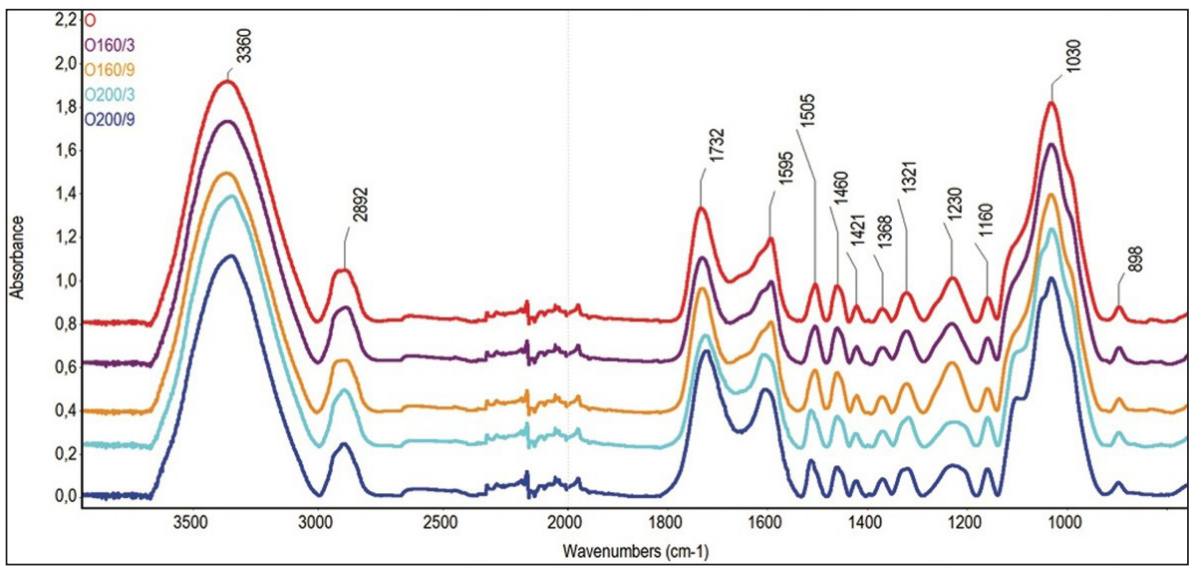

Fig. 5: FTIR spectra of non-treated and thermally treated Sessile oak (Quercus petraea L.) wood.

In the FTIR spectra of oak wood, the carbonyl peak at $1732 \mathrm{~cm}^{-1}$ initially at the temperature of $160^{\circ} \mathrm{C}$ and the time $3 \mathrm{hrs}$ mildly decreased. The decrease at the beginning of the heat treatment might be due to the breaking of acetyl or acetoxy groups in xylan. However, at longer treatment time and at the temperature of $200^{\circ} \mathrm{C}$ it markedly increased. Heating in air causes oxidation of the hydroxyl groups resulting in an increase of carbonyl and subsequently of carboxyl groups (Fengel and Wegener 1984). Furthermore, with increasing treatment severity, the shift in a maximum from $1732 \mathrm{~cm}^{-1}$ to $1720 \mathrm{~cm}^{-1}$ was observed. This appearance also suggested that in the wood components new carbonyl or carboxyl groups are formed (Esteves et al. 2013).

In the non-treated Sessile oak wood spectra the characteristic peak for aromatic ring at $1505 \mathrm{~cm}^{-1}$ can be observed. The maximum of mentioned peak shifts to $1514 \mathrm{~cm}^{-1}$ with increasing temperature and treatment duration. A similar trend was observed also by Geffert et al. (2019) in the case of oak wood steaming. According to Faix (1991), this band 
has maximum at about $1505 \mathrm{~cm}^{-1}$ for hardwood lignin and at about $1510 \mathrm{~cm}^{-1}$ for softwood lignin. Shifting the maximum of this peak to higher wavenumber can be due to the decrease of the methoxyl groups in lignin which would lead to a lignin more similar to softwood or to the loss of syringyl units. Syringyl monomers are generally less condensed by $\mathrm{C}-\mathrm{C}$ bonds than guaiacyl monomers and are more liable to be released by a thermal degradation (Faix et al. 1990).

The decrease in the intensity of absorption band at $1243 \mathrm{~cm}^{-1}$ in spectra of oak wood suggests that mainly at the temperature of $200^{\circ} \mathrm{C}$ the degradation of more labile hemicelluloses occurred. The process begins with the partial degradation of long hemicellulose chains into shorter ones and then follows with their decomposition through monosaccharides to volatile products (Hill 2006). In accordance with the findings of other authors (Výbohová et al. 2018, Ćabalová et al. 2018) it can be assumed that the earlier degradation of hemicelluloses increases the proportion of lignin in Sessile oak wood relatively. According to Sun et al. (2019) increase of the relative content of lignin and extractives after degradation of hemicelluloses by thermovacuum treatment of eucalyptus wood results in decrease in $\mathrm{O} / \mathrm{C}$ ratio. Because hemicelluloses have a low calorific value and lignin, on the other hand, a high calorific value, GCV values of Sessile oak wood increase due to degradation of hemicelluloses with increasing temperature and time of thermal treatment.

\section{CONCLUSIONS}

The effect of thermal treatment under various process conditions (at temperatures of 160 and $200^{\circ} \mathrm{C}$, duration of 3 and $9 \mathrm{hrs}$ ) on the gross calorific value of Scots pine (Pinus sylvestris L.) and Sessile oak (Quercus petraea L.) wood were studied. The value of GCV of untreated Scots pine wood was higher than in the case of Sessile oak wood. It is because softwoods contain more lignin and resins than hardwoods and just these components increase the calorific value of wood. The different composition of Scots pine and Sessile oak wood also influences their behaviour during thermal treatment. With increasing temperature and thermal treatment duration, the mass loss of both tree species increased but at $160^{\circ} \mathrm{C}$ the mass loss was higher for Scots pine samples, while at $200^{\circ} \mathrm{C}$ for Sessile oak samples. Whereas the calorific value of Scots pine wood with increased severity of treatment decreased, in the case of Sessile oak it increased. Mentioned differences in Scots pine and Sessile oak wood behaviour using ATR-FTIR spectroscopy were explained. In the case of Scots pine wood with increasing temperature and time of exposure a decrease of resin acids was observed. The decomposition of these compounds contributes to decrease in GCV. In the case of Sessile oak wood, mainly at temperature of $200^{\circ} \mathrm{C}$ the degradation of hemicelluloses was observed that results in higher mass loss at this temperature. Reducing the hemicelluloses content of the wood, the lignin content increases relatively, resulting in an increase in the GCV.

\section{ACKNOWLEDGMENT}

This work was supported by Slovak Research and Development Agency under the contract No. APVV-17-0005 (50\%) and project VEGA V-1/0493/18 (50\%). 


\section{REFERENCES}

1. Alakangas, E., 2005: Properties of wood fuels used in Finland. Technical research centre of Finland. Jyväskylä, 90 pp.

2. Andor, T., Lagaňa, R., 2018: Selected properties of thermally treated ash wood. Acta Facultatis Xylologiae Zvolen 60(1): 51-60.

3. Baeza, J., Freer, J., 2001: Chemical characterization of wood and its components. In: Wood and Cellulosic Chemistry (ed. Hon DNS., Shiraishi N)., Marcel Dekker Inc. New York, Pp 275-384.

4. Barcík, Š., Gašparík, M., Razumov, E. Y., 2015: Effect of temperature on the color changes of wood during thermal modification. Cellulose Chemistry and Technology 49(9-10): 789-798.

5. Bazyar, B., 2012: Decay resistance and physical properties of oil heat treated aspen wood. BioResources 7(1): 696-705.

6. Bubeníková, T., Luptáková, J., Kačíková, D., Kačík, F., 2018: Characterization of macromolecular traits of lignin from heat treated spruce wood by size exclusion chromatography. Acta Facultatis Xylologiae Zvolen 60(2): 33-42.

7. Brebu, M., Vasile, C., 2010: Thermal degradation of lignin - A review. Cellulose Chemistry and Technology 44(9): 353-363.

8. Čabalová, I., Kačík, F., Lagaňa, R., Výbohová, E., Bubeníková, T., Čaňová, I., Ďurkovič, J., 2018: Effect of thermal treatment on the chemical, physical, and mechanical properties of pedunculate oak (Quercus robur L.) wood. BioResources 13(1): 157-170.

9. Cademartori, P.H.G., Missio, A.L., Mattos B.D., Gatto D.A., 2015: Effect of thermal treatments on technological properties of wood from two Eucalyptus species. Anais da Academia Brasileira de Ciências 87(1): 471-481.

10. Candelier, K., Thevenon, M.F., Petrissans, A., Dumarcay, S., Gerardin, P., Petrissans, M., 2016: Control of wood thermal treatment and its effects on decay resistance: a review. Annals of Forest Science 73: 571-583.

11. Chen, Y., Gao, J., Fan, Y., Tshabalala, M.A., Stark, N.M., 2012: Heat-induced chemical and color changes of extractive-free Black Locust (Robinia pseudoacacia) wood. BioResources 7(2): 2236-2248

12. Dietenberger, M.A., Hasburgh, L.E., 2016: Wood products: Thermal degradation and fire. Pp 9712-9716, USDA Forest Products Laboratory, Madison.

13. Dubey, M.K., Pang, S., Walker, J., 2012: Changes in chemistry, color, dimensional stability and fungal resistance of Pinus radiata D. Don wood with oil heat-treatment. Holzforschung 66(1): 49-57.

14. Dzurenda, L., 2018: The shades of color of Quercus robur L. wood obtained through the processes of thermal treatment with saturated water vapor. BioResources 13(1): 1525-1533.

15. Dzurenda, L., Pňakovič, L', 2016: Influence of the burning temperature of the non-volatile combustible content of wood and bark of plantation-grown, fast-growing tree species upon ash production, and its properties in terms of fusibility. BioResources 11(3): 6464-6476.

16. Dzurenda, L., Ridzik, L., Dzurenda, M., 2013: Popolnatost' biopaliva - energetickej štiepky z dendromasy porastov plantážnicky pestovaných vŕb a topolov (Ash of biofuels green wood chips made of dendromass from willows and poplars grown on plantations). Acta Facultatis Xylologiae Zvolen 55(1): 111-118. 
17. Ekeberg, D., Flæte, P.O., Eikenes, M., Fongen, M., Naess-Andresen, C.F., 2006: Qualitative and quantitative determination of extractives in heartwood of Scots pine (Pinus sylvestris L.) by gas chromatography. Journal of Chromatography A 1109(2): 267-272

18. Esteves, B.M., Pereira, H.M., 2009: Wood modification by heat treatment: A review. BioResources 4(1): 370-404.

19. Esteves, B., Velez Marques, A., Domingos, I., Pereira, H., 2013: Chemical changes of heat treated pine and eucalypt wood monitored by FTIR. Maderas. Ciencia y tecnología 15(2): 245-258.

20. Esteves, B., Videira, R., Pereira, H., 2011: Chemistry and ecotoxicity of heat-treated pine wood extractives. Wood Science and Technology 45: 661-676.

21. Faix, O., 1991: Classification of lignins from different botanical origins by FT-IR spectroscopy. Holzforschung 45(s1): 21-27.

22. Faix, O., Meier, D., Fortmann, I. 1990: Thermal degradation products of wood. Holz als Roh-und Werkstoff 48: 351-354.

23. Fengel, D., Wegener, G., 1984: Wood - Chemistry, ultrastructure, reactions. Walter de Gruyter. Berlin and New York, 613 pp.

24. Geffert, A., Výbohová, E., Geffertová, J., 2019: Changes in the chemical composition of oak wood due to steaming. Acta Facultatis Xylologiae Zvolen 61(1): 19-29.

25. Geffertová, J., 2009: Heating value of hydrolysed birch wood. Acta Facultatis Xylologiae Zvolen 51(2): 63-69.

26. Gonzalez-Pena, M.M., Curling, S.F., 2009: On the effect of heat on the chemical composition and dimensions of thermally-modified wood. Polymer Degradation and Stability 94(12): 2184-2193.

27. Hill, C.A.S., 2006: Wood Modification. Chemical, thermal, and other processes. John Wiley \& Sons. Chichester, 239 pp.

28. Hon, D.N.S, Shiraishi, N., 2001: Wood and cellulosic chemistry. Marcel Dekker, New York, $914 \mathrm{pp}$.

29. ISO 1928, 2009: Solid mineral fuels. Determination of gross calorific value by the bomb calorimetric method and calculation of net calorific value.

30. Klement, I., Réh, R., Detvaj, J., 2010: Základné charakteristiky lesných drevín drevín (Basic characteristics of forest trees ). NLC Zvolen, $82 \mathrm{pp}$.

31. Kúdela, J., Andor, T., 2018: Beech wood discoloration induced with specific modes of thermal treatment. Annals of Warsaw University of Life Sciences - SGGW, Forestry and Wood Technology 103: 64-69.

32. Luptáková, J., Kačík, F., 2018: The influence of thermal modification on selected wood properties. Delta: Fire Protection \& Safety Scientific Journal 12(1): 33-43.

33. Majlingova, A., Lieskovsky, M., Zachar, M., 2019: Fire and energetic properties of selected fast-growing tree species and energy crop species. Technical University in Zvolen, $178 \mathrm{pp}$.

34. Martinka, J., Hroncová, E., Chrebet, T., Balog, K., 2013: Fire risk assessment of thermally modified spruce wood. Acta Facultatis Xylologiae Zvolen 55(2): 117-128.

35. Mazela, B., Zakrzewski, R., Grzeskowiak, W., Cofta, G., Bartkowiak, M., 2003: Resistance of thermally modified wood to basidiomycetes. Electronic journal of Polish agricultural universities 7(1): \#3 (published online), 7pp.

36. Militz, H., 2002: Heat treatment technologies in Europe: Scientific background and technological state-of-art. In: Enhancing the durability of lumber and engineered wood product., Forest Products Society. Madison, Pp 239-249.

37. Nosek, R., Holubčík, M., 2016: Energy properties of air dry firewood. Acta Facultatis Xylologiae Zvolen 58(1): 105-112. 
38. Percin, O., Peker, H., Atilgan, A. 2016: The effect of heat treatment on the some physical and mechanical properties of beech (Fagus orientalis Lipsky) wood. Wood Research 61(3): 443-456.

39. Reinprecht, L., Vidholdová, Z., 2011: Termodrevo. Thermowood. Šmíra - Print s.r.o, Česká republika, 89 pp.

40. Santos, R.B., Capanema, E.A., Balakshin, M.Y., Chang, H., Jameel, H., 2012: Lignin structural variation in hardwood species. Journal of Agricultural and Food Chemistry 60(19): 4923-4930.

41. Severo, E.T.D., Calonego, F.W., Sansígolo, C.A., Bond, B., 2016: Changes in the Chemical composition and decay resistance of thermally-modified Hevea brasiliensis wood. PLOS One 11(3): e0151353.

42. Sun, B., Wang, Z., Liu, J., 2019: Study on color and surface chemical properties of Eucalyptus pellita wood subjected to thermos-vacuum treatment. Wood Research 64(1): 01-12.

43. Telmo, C., Lousada, J., 2011: The explained variation by lignin and extractive contents on higher heating value of wood. Biomass and bioenergy 35(5): 1663-1667.

44. Tillman, D. A., 1978: Wood as an Energy Resource. New York: Academie Press, 252 pp.

45. White, R., 1986: Effect of lignin content and extractives on the higher heating value of wood. Wood and Fiber Science 19(4): 446-452.

46. Traoré, M., Kaal, J., Cortizas, A.M., 2018: Differentiation between pine woods according to species and growing location using FTIR-ATR. Wood Science and Technology 52: 487-504.

47. Výbohová, E., Kučerová, V., Andor, T., Balážová, Ž., Velková, V., 2018: The effect of heat treatment on the chemical composition of ash wood. BioResources 13(4): 8394-8408.

48. Wang, X., Wu, Z., Fang, L., Wei, P., Fei, B., Liu, J., 2015: Changes of chemical composition, crystallinity, and Fourier transform infrared spectra of Eucalypt pellita wood under different vacuum heat treatment temperatures. Forest Products Journal 65(7-8): 346-351.

49. Wikberg, H., Maunu, S.L., 2004: Characterization of thermally modified hard- and softwoods by 13C CPMAS NMR. Carbohydrate Polymers 58(4): 461-466.

\author{
Emília Orémusová \\ Technical University In Zvolen \\ Faculty Of Wood Sciences And Technology \\ Department Of Fire Protection \\ T. G. Masaryka 24 \\ 9600 I Zvolen \\ Slovak Republic \\ Eva Vи́воноvá* \\ Technical University In Zvolen \\ Faculty Of Wood Sciences And Technology \\ Department Of Chemistry And Chemical Technologies \\ T. G. Masaryka 24 \\ 9600i ZVOLEN \\ Slovak Republic \\ *Corresponding author: eva.vybohova@tuzvo.sk
}

